\title{
MANAJEMEN PENGELOLAAN ZAKAT BAGI PENGURUS MASJID
}

\author{
Nurul Huda, Zulihar, dan Hulmansyah \\ Program Magister Manajemen, Universitas YARSI \\ E-mail : nurul.huda@yarsi.ac.id
}

\begin{abstract}
ABSTRAK
Ta'mir Masjid adalah organisasi kelembagaan Masjid yang terdiri dari beberapa orang dan mempunyai kewajiban memakmurkan Masjid. Pemahaman yang masih rendah dalam manajemen pengelolalan ZISWAF sehingga diperlukan penuluhan dan pendampingan bagi Pengurus Masjid dalam melakukan Pengelolaan Zsiwaf. Metode yang dilakukan dengan menggunakan dua pendekatan yaitu pelatihan dan pendampingan. Hasil pelatihan Pengurus mulai memahami manajemen pengelolaan ziswaf baik pengumpulan maupun pendistrusian dan pendayagunaan dana ziswaf.
\end{abstract}

\section{PENDAHULUAN}

Studi yang dilakukan oleh PIRAC pada tahun 2004 mengestimasikan potensi zakat di Indonesia mencapai Rp. 6.132 triliun (Kurniawati, 2004). Studi yang dilakukan oleh Firdaus dkk (2012) menunjukkan total seluruh potensi zakat di Indonesia dari berbagai sumber yakni pendapatan rumah tangga, pendapatan perusahaan, dan tabungan diestimasikan sebesar Rp. 217 triliun atau setara dengan $3.4 \%$ PDRB Indonesia tahun 2010

Riset yang dilakukan Huda et.al (2014) ditemukan regulator zakat dinilai sebagai lembaga yang paling bermasalah dalam pengelolaan zakat nasional diikuti OPZ (Organisasi Pengelola Zakat) dan Muzaki-Mustahik. Hasil riset Huda et.al (2014) menunjukkan bahwa lembaga yang paling berperan untuk menjadi penyelesaian masalah pengelolaan zakat nasional adalah OPZ.Karena bagaimanapun juga OPZ adalah lembaga yang paling berperan dalam pengelolaan zakat yang berinteraksi langsung dengan masyarakat.Prioritas solusi yang dapat dilakukan oleh OPZ dari hasil riset Huda et.al (2014) adalah peningkatan transparansi dan akuntabilitas serta standarisasi pengelolaan zakat nasional serta peningkatan efektifitas program pendayagunaan untuk kemaslahatan mustahik.

Lembaga zakat yang disebut dengan organisasi pengelola zakat banyak tersebar di Indonesia. Lembaga zakat tersebut ada yang merupakan lembaga swadaya masyarakat dan ada yang dibentuk oleh pengurus masjid. 
Masjid sebagai agen BAZNAS, tentu menjadikan masjid sebagai lembaga atau badan formal yang diakui Negara dalam melaksanakan pengumpulan zakat. Ini berarti bahwa keberadaan masjid sebagai pengumpul zakat bukan lembaga yang illegal.

Pengelolaan zakat yang professional, akuntabel, mudah dan distribusi yang merata bagi Mustahik menjadikan sebuah keharusan yang dilaksanakan oleh seluruh pemangku kebijakan, khususnya Negara melalui Badan Amil Zakat Nasional (BAZNAS). Keberadaan BAZNAS sebagai lembaga yang mengelola zakat saat ini perlu melakukan ekspansi dan pengembangan dalam rangka penguatan dan peningkatan penerimaan zakat hingga level masjid. Hal ini karena masjid merupakan tempat ibadah yang langsung bersentuhan dengan seluruh elemen masyarakat. Maka, sudah selayaknya masjid menjadi agen BAZNAS yang penerima dan penyalurkan zakat akan meningkatkan gairah masyarakat untuk menyalurkan zakat dan pemerataan pendistribusiannya dalam rangka meningkatkan taraf hidup masyarakat muslim.
Masjid sebagai agen penerima zakat Baznas tentu harus di dukung oleh sumber daya manusia (SDM) pengelola masjid atau ta'mir masjid tersebut yang profesional dan akuntabel. SDM yang professional dilatarbelakangi oleh beberapa faktor, diantaranya pendidikan, pengalaman, dan ketelitian. Hal ini supaya maksud tujuan masjid sebagai penerima zakat masyarakat diatas benar-benar bisa tercapai. Selama ini, peran ta'mir dalam mengelola zakat baru sebatas rutinan atas zakat fitrah atau zakat jiwa yang dikeluarkan selama bulan ramadlan. Maka, tidak menutup kemungkinan ta'mir masjid tersebut mampu mengelola zakat maal yang sifatnya berlaku terus setiap hari atau sebaliknya merasa belum mampu untuk menjadi agen Baznas (Arafa et al, 2017)

Ta'mir Masjid adalah organisasi kelembagaan masjid yang terdiri dari beberapa orang dan mempunyai kwajiban memakmurkan masjid. Selain itu, ta'mir masjid sebenarnya telah bermakna kepengurusan masjid, namun tidak salah jika menyebut "Pengurus Takmir Masjid”. Hal ini sesuai dengan firman Allah SWT

"Sesungguhnya orang-orang yang memakmurkan masjid Allah ialahorang-orang yang beriman kepada 
Allah dan hari akhir, menegakkan shalat, mengeluarkan zakat dan tidak takut kecuali hanya kepada Allah. Karena itu semoga mereka termasuk orang-orang yang mendapat hidayah". (QS. At-Taubah : 18).

Adapun kegiatan yang dilakukan ta'mir masjid meliputi idaroh atau kegiatan administrasi, imaroh atau kegiatan-kegiatan yang mengarah kepada pembinaan jamaah serta ri'ayah, yaitu kegiatan yang berkaitan dengan pembangunan fisik (sarana dan prasarana).

Takmir masjid yang mayoritas bersedia menjadi agen Baznas dalam menerima zakat maal memerlukan pengetahuan, pemahaman dan standarisasi pengelolaan zakat, baik secara manual maupun secara on-line real time.Selain itu, sosialisasi kepada seluruh lapisan masyarakat terutama mereka yang sudah berkewajiban mengeluarkan zakat maal untuk disalurkan kepada organisasi pengelola zakat terdekat.

Secara umum persoalan yang muncul bagi Takmir masjid dalam mengelola zakat, yaitu masih rendahnya pengetahuan tentang pengelolaan zakat baik dari sisi model penghimpunan zakat maupun dalam penyaluran zakat yang masih sangat tradisional.

\section{KHALAYAK SASARAN}

Pelatihan dilakukan bagi Pengurus Masjid yang berada disekitar Universitas YARSI (Target minimal 10 Masjid) dengan perwakilan masjid masing-masing Minimal 3 Orang.

\section{METODE KEGIATAN}

Model yang akan dipergunakan adalah :

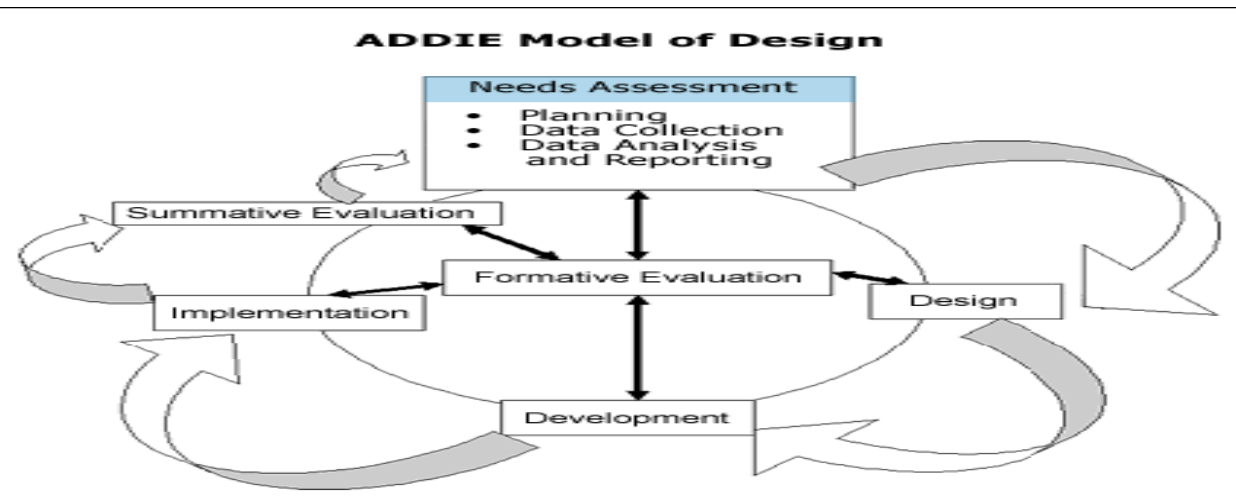




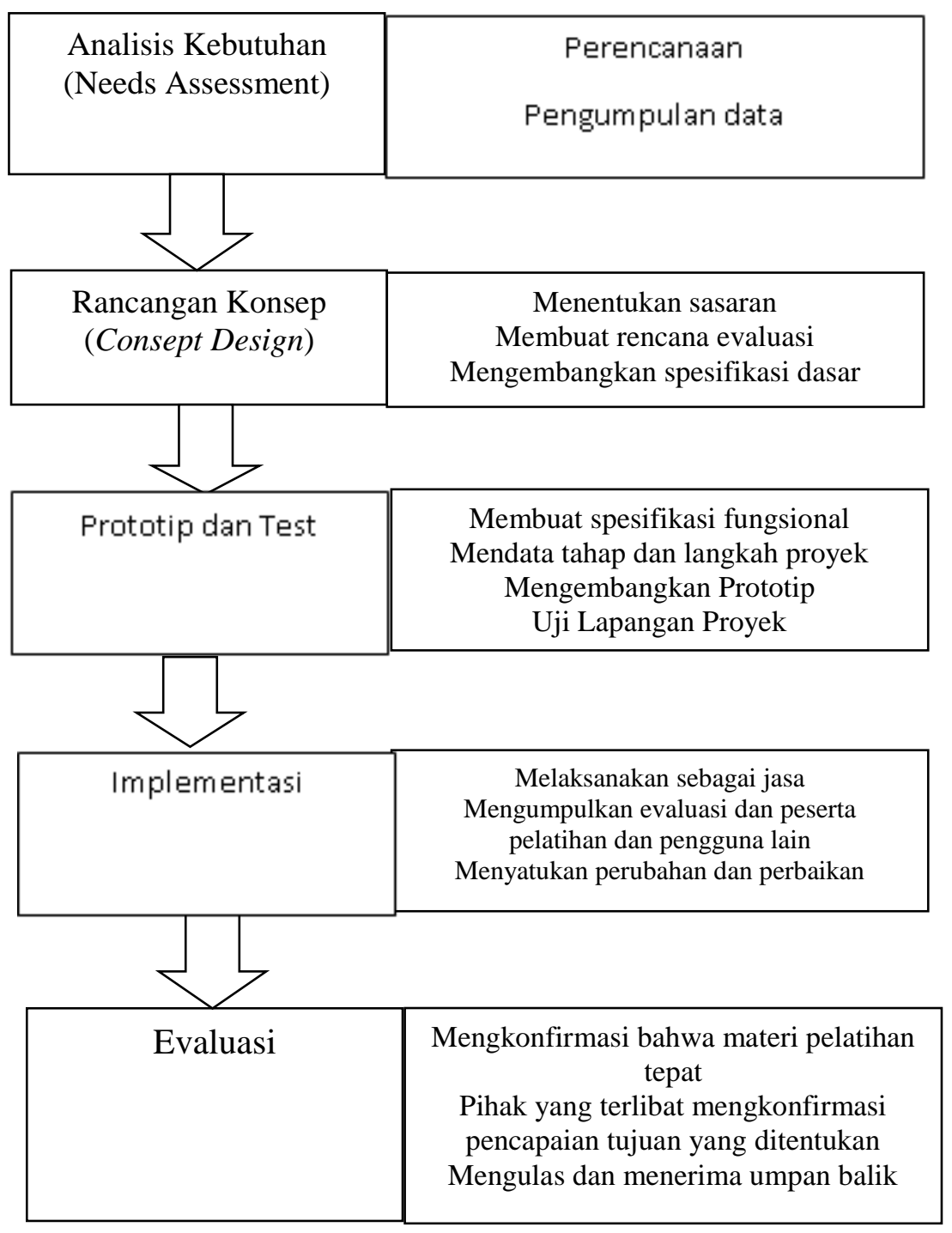

\section{HASIL DAN PEMBAHASAN}

\section{Deskripsi Peserta Kegiatan}

Kegiatan penyuluhan atau sharing bagi pengurus Masjid di Lingkungan Universitas YARSI dihadiri 25 Peserta yang meliputi : Ketua DKM, pengurus Masjid (Sekretaris Masjid, Sie Ubudiyah. Adapun Identitas pribadi lengkap peserta sebagai berikut :

\section{Usia Peserta}

Peserta di dominasi usia > 40 tahun sebanya 9 orang $(36 \%)$ diikuti usia $30-40$ sebanyak 8 orang $(32 \%)$ sehingga hampir $68 \%$ pengurus Masjid yang hadir berusia 30 tahun ke atas. Berikut Gambaran lengkapnya 


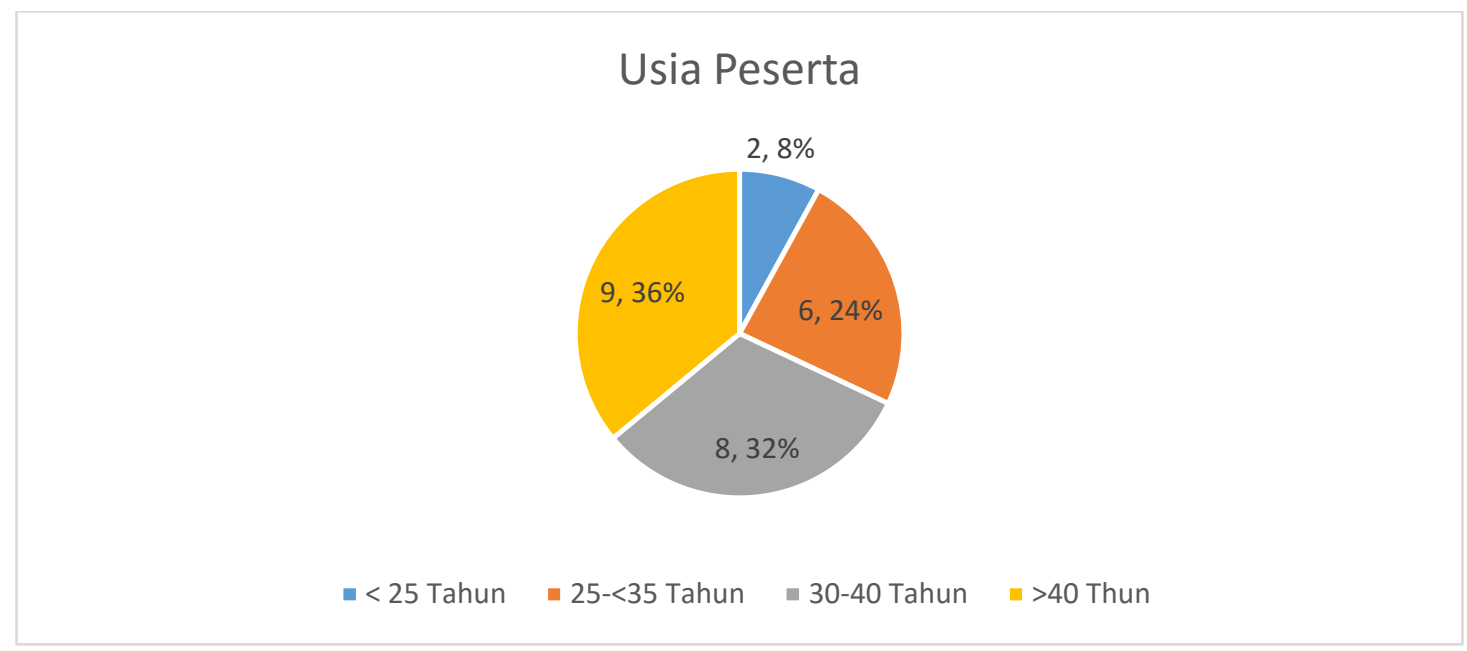

Gambar 1. Usia Peserta

Sumber : Kuesioner (2020), data diolah

2. Pekerjaan Peserta

Pekerjaan Peserta kegiatan ini sangat

beragam dari kalangan Mahasiswa,

Pegawai, wiraswasta dan lainnya.
Dominasi pekerjaan pada

Wiraswasta dan Pegawai, berikut

informasi pekerjaan para peserta

\section{Pekerjaan Peserta}

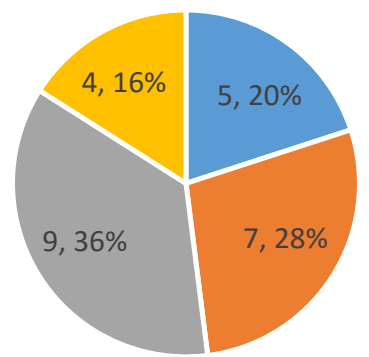

- Mahasiswa - PNS/Swasta "Wiraswasta - Lainnya

Gambar 2 Pekerjaan Peserta

Sumber : Kuesioner (2020), data diolah 
3. Status Peserta

Peserta yang hadir ada yang langsung sebagai Ketua Dewan Kemakmuran Masjid (DKM), Wakil Ketua DKM, Sekretais DKM,
Pengurus Masjid untuk bidang seksi tertentu. Pesrta di Dominasi, 16 Peserta sebagai Penguus Masjid dan Anggota serta Partisipan, berikut gambaran status peserta

\section{Status Peserta}

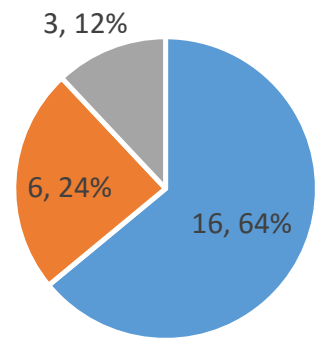

- Pengurus - Anggota - Partisipan

\section{Gambar 3 Status Peserta}

Sumber : Kuesioner (2020), data diolah

4. Kegiatan Pengajin Di Masjid

Kegaiatan yang dilakukan di masjid berupa kajian dilakukan dalam mingguan atau tiap bulanan, hadir menyatakan kegiatan kajian dilakukan bersifat mingguan, ini tentu semakin menghidupkan suasana masjid

Dominan dari pengurus Masjid yang

\section{Kegiatan Kajian Rutin Masjid}

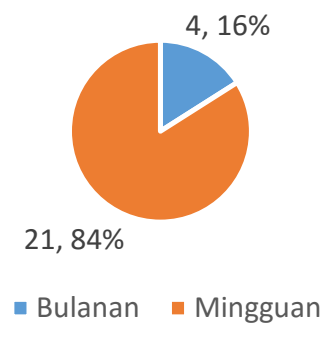

Gambar 4 kegiatan kajian rutin Masjid

Sumber : Kuesioner (2020), data diolah 
5. Tema Kajian

Tema kajian di Masjid dalam hal ini dikelompokkan pada dua kajian besar yaitu Ibadah dan Mumalah, penguru Masjid yang hadir menyatakan tema kajian Ibadah lebih dominan dibandingkan Mumalah. Ke depan sedapat mungkin kajian yang dilakukan harus seimbang anatara ibadah dan Muamalah

\section{Tema Kajian Masjid}

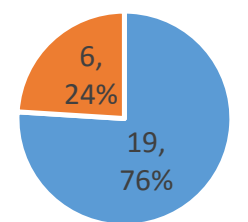

- Ibadah " Muamalah

Gambar 5 Tema Kajian Masjid Sumber : Kuesioner (2020), data diolah

6. Sumber Utama Penerimaan Masjid

Biasanya ada 3 sumber utama penerimaan Masjid yaitu Infaq dan sedekah, Zakat dan Wakaf, Pengurus
Masjid yang hadir menyatakan sumber penerimaan terbesar dari infaq dan sedekah sebanyak $84 \%$

\section{Penerimaan Utama Masjid}

4, $16 \%$

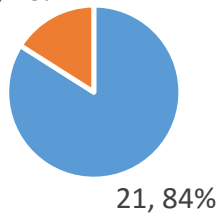

- Infaq dan Shadaqah = Zakat

Gambar 6 Penerimaan Utama Masjid

Sumber : Kuesioner (2020), data diolah 
7. Jumlah Jamaah Masjid Setiap Ada Kajian

Kehadiran Jamaah tentu menjadi harapan bagi para Pengurus Masjid dalam setiap kajian yang dilakukan, dari pengurus yang hadir menyatakan $60 \%$ pengurus menyatakan di atas 50 Jamaah yang hadir setipa kajian

\section{Jumlah Jamaah Setiap Kajian di Masjid}

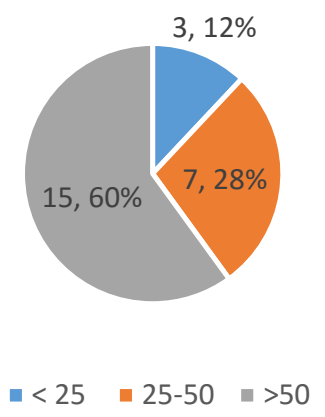

Gambar 7 Penerimaan Utama Masjid

Sumber : Kuesioner (2020), data diolah

Kemampuan Pre Test dan Post Test

Pre Test

Ada 10 pertanyaan yang diajukan, sebelum kegiatan penyuluhan atau sharing dilakukan, peserta harsu menjawab pertanyan dengan pengetahuan yang dimiliki masingmasing. 
Tabel 1 Nilai Pre Test

Skor

\begin{tabular}{|c|c|c|c|c|c|}
\hline & & Frequency & Percent & $\begin{array}{c}\text { Valid } \\
\text { Percent }\end{array}$ & $\begin{array}{c}\text { Cumulative } \\
\text { Percent }\end{array}$ \\
\hline \multirow{8}{*}{ Valid } & ,00 & 1 & 4,0 & 4,0 & 4,0 \\
\hline & 20,00 & 4 & 16,0 & 16,0 & 20,0 \\
\hline & 30,00 & 10 & 40,0 & 40,0 & 60,0 \\
\hline & 40,00 & 4 & 16,0 & 16,0 & 76,0 \\
\hline & 50,00 & 3 & 12,0 & 12,0 & 88,0 \\
\hline & 60,00 & 2 & 8,0 & 8,0 & 96,0 \\
\hline & 70,00 & 1 & 4,0 & 4,0 & 100,0 \\
\hline & Total & 25 & 100,0 & 100,0 & \\
\hline
\end{tabular}

Sumber : Kuesioner (2020), data diolah

Berdasarkan tabel 1 terlihat bahwa 10 Peserta mendapatkan nilai 30 yang berarti 3 soal yang dijawab benar dari 10 soal yang ada. Selain itu hanya ada 3 Peserta yang nilainya di atas 50, Ada juga 1 peserta yang mendapatkan nilai 0. Berdasarkan gambaran ini jelas bahwa pemhaman Pengurus Masjid terkait infaq, sedekah, zakat dan wakaf serta bagaimana melakukan pengelolaannya masih sangat rendah sebelum dilakukan pelatiha atau sharing.

\section{Post Test}

Sebelum post test dilakukan maka peserta mendapatkan penyuluhan dan sharing materi yang dimulai dari pengetahuan tentang ZISWAF baik persamaan maupun perbedaannya, serta
Model-model yang bisa dikembangkan dalam penghimpunan maupun penditribusian ZISWAF dengan tetap memperhatikan dasar hukum syar'i. Peserta diberikan pula kesempatan untuk menyampaikan permasalahan di Masjidnya masing-masing dalam persoalan pengelolaan ziswaf. Berdasarkan hasil diskusi maka pesoalan banyak pada Rendahnya pemhaman Amil zakat khususnya dalam melakukan pengelolaan dana zakat. Karena terkait zakat memang sudah diatur dengan tegas khususnya terkait peruntukkannya yaitu pada 8 Asnaf.

Setelah dilakukan penyuluhan dan sharing maka peserta kembali diminta untuk mengikuti post test dengan soal yang sama pada saat pretest 
Tabel 2 Nilai Post Test

Skor

\begin{tabular}{rrrrr}
\hline & Frequency & Percent & $\begin{array}{c}\text { Valid } \\
\text { Percent }\end{array}$ & $\begin{array}{c}\text { Cumulative } \\
\text { Percent }\end{array}$ \\
\hline 10,00 & 1 & 4,0 & 4,0 & 4,0 \\
40,00 & 2 & 8,0 & 8,0 & 12,0 \\
50,00 & 7 & 28,0 & 28,0 & 40,0 \\
60,00 & 5 & 20,0 & 20,0 & 60,0 \\
Valid & 3 & 12,0 & 12,0 & 72,0 \\
70,00 & 4 & 16,0 & 16,0 & 88,0 \\
80,00 & 2 & 8,0 & 8,0 & 96,0 \\
90,00 & 1 & 4,0 & 4,0 & 100,0 \\
100,00 & 25 & 100,0 & 100,0 & \\
\hline Total & & & & \\
\hline
\end{tabular}

Sumber : Kuesioner (2020), data diolah

Berdasarkan tabel 2 terlihat 15 yang mendapatkan nilai 100 artinya peserta nilainya sudah berada di atas 50 semua soal di jawab dengan benar. dan peserta yang nilainya 50 ada Hasil uji Paired sampel test sebelum dan sebanyak tujuh peserta dan yang di sesuadah pelatihan dapat dijelaskan bawah 50 hanya ada 3 peserta. Satu hal sebagai berikut : yang sangat luarbiasa ada satu peserta

Tabel 3 Paired Samples Statistics

\begin{tabular}{llllcr}
\hline & & Mean & N & $\begin{array}{c}\text { Std. } \\
\text { Deviation }\end{array}$ & $\begin{array}{c}\text { Std. Error } \\
\text { Mean }\end{array}$ \\
\hline \multirow{2}{*}{ Pair 1 } & pretest & 35,2000 & 25 & 15,30795 & 3,06159 \\
& posttest & 62,0000 & 25 & 19,57890 & 3,91578 \\
\hline
\end{tabular}

Sumber : Kuesioner (2020), data diolah 
Nilai yang diperoleh peserta pelatihan dengan diberikan soal yang sebelum pretest rata rata 35,2 (skala sama maka diperoleh rata-rata nilai 100) bahkan ada peserta hanya 62,00 (skala 100) dan nilai terendah 40 mendapatkan skor 0 dan ada juga yang bahkan 1peserta mendapatkan nilai 100 . mendapatkan skor 70. Setelah diberikan

Tabel 4 Paired Samples Correlations

\begin{tabular}{llccc}
\hline & N & $\begin{array}{c}\text { Correlatio } \\
\text { n }\end{array}$ & Sig. \\
\hline Pair 1 & $\begin{array}{l}\text { pretest \& } \\
\text { posttest }\end{array}$ & 25 &, 214 &, 304 \\
\hline
\end{tabular}

Sumber : Kuesioner (2020), data diolah

Berdasarkan tabel 4 terlihat nilai korelasi sebesar 0,214 atau 21,4 \% hubungan antara sebelum dan sesudah pelatihan tetapi pelatihan ini secara signifikan menambah pengetahuan peserta seperti terlihat pada tabel di bawah ini :

Tabel 5 Paired Samples Test

\begin{tabular}{|c|c|c|c|c|c|c|c|c|c|}
\hline & & \multicolumn{5}{|c|}{ Paired Differences } & \multirow[t]{3}{*}{$\mathrm{t}$} & \multirow[t]{3}{*}{ df } & \multirow{3}{*}{$\begin{array}{l}\text { Sig. } \\
(2- \\
\text { tailed } \\
\text { ) }\end{array}$} \\
\hline & & \multirow[t]{2}{*}{ Mean } & \multirow[t]{2}{*}{$\begin{array}{c}\text { Std. } \\
\text { Deviation }\end{array}$} & \multirow{2}{*}{$\begin{array}{l}\text { Std. } \\
\text { Error } \\
\text { Mean }\end{array}$} & \multicolumn{2}{|c|}{$\begin{array}{l}95 \% \text { Confidence Interval } \\
\text { of the Difference }\end{array}$} & & & \\
\hline & & & & & Lower & Upper & & & \\
\hline Pair 1 & $\begin{array}{l}\text { pret } \\
\text { est - } \\
\text { postt } \\
\text { est }\end{array}$ & $\begin{array}{r}- \\
26,8000 \\
0\end{array}$ & 22,12088 & 4,42418 & $-35,93105$ & $\begin{array}{r}- \\
17,6689\end{array}$ & $6,058^{-}$ & 24 & 000 \\
\hline
\end{tabular}


Berdasarkan nilai Sig 0,000 yang berarti $<0,05$ maka pelatihan signifikan mempengaruhi pengetahuan peserta.

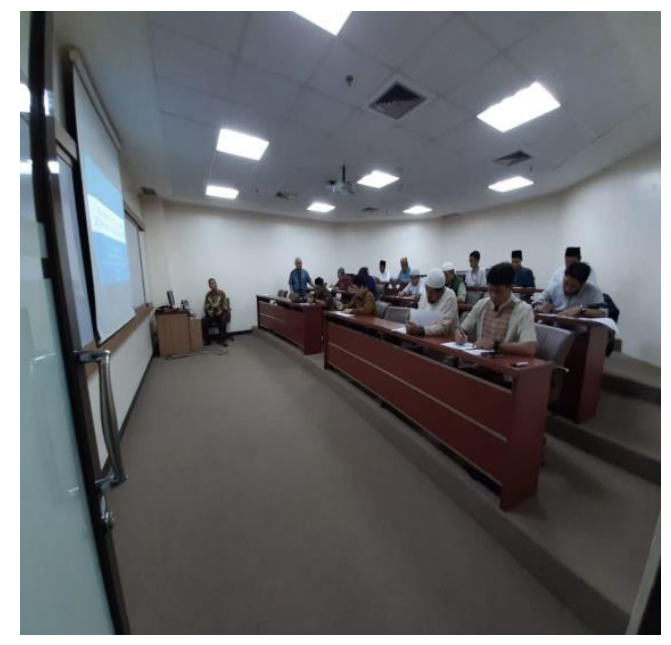

Gambar 8 Suasana Pre test

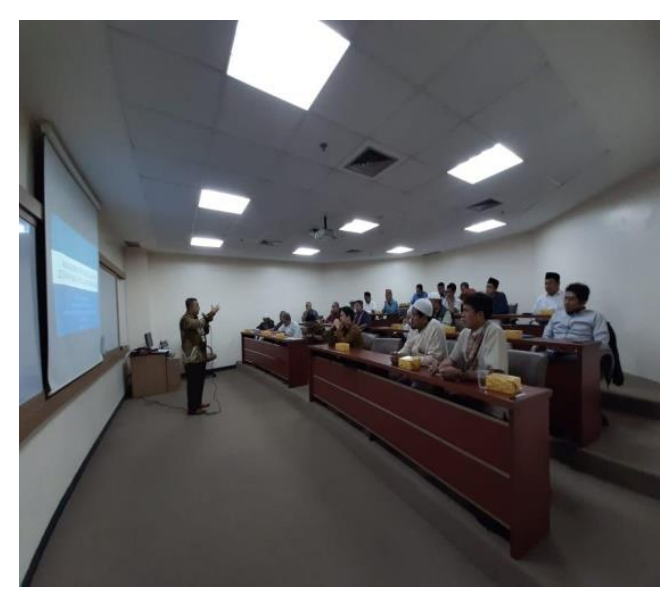

Gambar 9 Suasana Post test

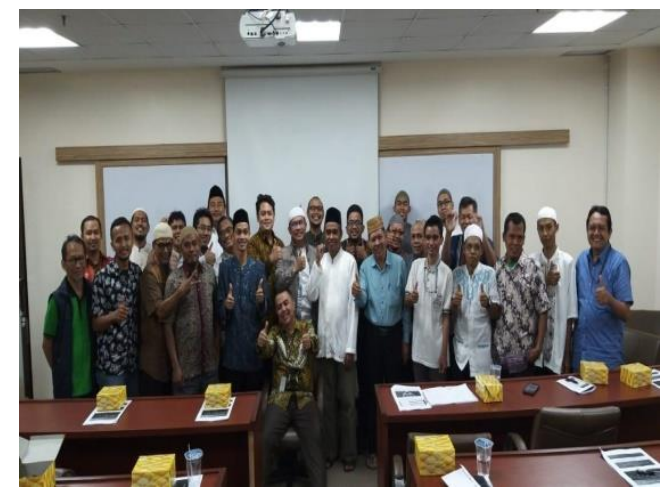

Gambar 10 Foto Narasumber dan

Peserta

\section{KESIMPULAN}

Kegiatan P2M ini yang berupa kegiatan pelatihan dan pendampingan secara umum sudah berjalan sesuai yang direncanakan. Peserta sangat antusias mengikuti pelatihan dan ada 5 Pengurus Masjid akan menindaklanjuti kegiatan ini dengan melakukan kegiatan pendalaman dan pendampingan

Hasil uji pre dan post test menunjukkan bahwa kegiatan pelatihan berpengaruh signifikan terhadap pengetahuan peserta tentang pengelolaan Ziswaf

\section{DAFTAR PUSTAKA}

Arafa, M. Husni, M. Husni Tamrin, Aan Zainul Anwar, Alex Yusron Al Muft. 2017. Masjid Sebagai Agen Baznas: Analisa Potensi SDM Ta'mir Masjid di Kabupaten Jepara, ulul albab: Jurnal Studi dan Penelitian Hukum Islam, Vol. 1, No. 1, Oktober 2017, 58-72

Firdaus, Muhammad, dkk. 2012. Economic Estimation and Determinations of Zakat Potential in Indonesia. IRTI Working Paper Series No. 1433-07. Jeddah: IRTI

Huda, Nurul., Anggraini, Desti., dan Ali, Khalifah Muhammad.2014. Solutions to Indonesian Zakah ProblemsAnalytic Hierarchy Process Aprroach. Journal of Islamic Economics, Banking and Finance, Vol. 10 No. 3, July - Sep 2014 
Huda, Nurul, Hulmansyah H, Zulihar Z. 2019. Wakap uang untuk Operasional Kegiatan Mesjid. J. Alikhlas. Vol 4 Nomor 2. Pp. 147160
Kurniawati. 2004. Kedermawanan kaum Muslimin : potensi dan realita zakat masyarakat di Indonesia. Jakarta: Piramedia (PIRAC) 